\title{
Proverbs of the Tatar People as Part of Ethnic Identity
}

\author{
Alfiya Shavketovna Yusupova
}

\author{
Gulnaz Rinatovna Mugtasimova
}

Guzel Amirovna Nabiullina

\author{
Elvira Nikolaevna Denmukhametova
}

Kazan Federal University, 420008, Kazan, Kremlevskaya St., 18

Doi:10.5901/mjss.2015.v6n6s2p161

\begin{abstract}
The offered article reveals ethnic identity research problems based on folklore materials such as Proverbs of the Tatar people. The assumption expresses and locates in the article that proverbs are reliable language source when designing ethnic identity. The special attention is paid to such values, as "Mine - Alien "and" Family. Determination of ethnic identity is actual because of an intensive process of globalization presently. Uncountable contacts between ethnos unify material and spiritual cultures of the nations, changes of habits and behavior of people, influences their values that leads to loss of individual and ethnic identity (Karabulatova, 2013; Karabulatova, Polivara \& Zamaletdinov, 2014; Sayfulina et al, 2013; Zamaletdinov et al, 2014 \& Karabulatova \& Akhmetova, 2015). The lost of cultural values even one small people conducts to the impoverishment of all humanity's culture. The knowledge of national features of ethnoses is of great importance for any multiethnic community leads to bigger mutual understandings, allows to prevent interethnic intensity and prevents conflict situations.
\end{abstract}

Keywords: ethnic identity, ethnic-differentiating sign, folklore, proverb, Tatar language.

\section{Introduction}

Globalization has sharply aggravated problems of preservating the linguistic and cultural identity of Tatars and Turkic people. In public discourse into the forefront fears to lose own identity act (Zamaletdinov et al, 2014).

Identity as a many-sided phenomenon and complex concept even more often became today object of research for various scientific disciplines (Ryazantsev et al, 2014; Ryazantsev et al, 2015 \& Pismennaya et al, 2015). Researchers of different branches direct the efforts to search for the hidden meanings using tools of science; however, the source of knowledge in most cases is language. Language is a confession of the people, and it is possible to hear its nature, soul and life (Hrolenko \& Bondaletov, 2004). It is hard to overestimate the importance of language as the people, and language can not be presented one without another. Language disappears and, as a result, the ethnic identity of its carriers is lost. Consequently, they passed and assimilated on another ethnic environment. (Karabulatova, Koyche \& Gultyaev, 2013; Karabulatova, Sayfulina \& Akhmetova, 2013 \& Yusupov \& Karabulatova, 2014). Each person feels the native language, its system influences on thinking manners and determinant of certain installations (Ostrovskaya et al, 2015; Khachmafova et al, 2015; Karabulatova \& Polivara, 2015 \& Ryazantsev et al, 2014). It is unconditional that Proverbs accumulate in themselves popular wisdom, but we have to recognize that their external registration is not the stiffened form, it also evolves together with ethnos, and during functioning there are invariants of these proverbs which staticizes certain semantic components of concrete expression.

All researchers note obvious interrelation of the people and language, to track ethnic identity in system of set expressions which proverbs, sayings, phraseological units and other paremias (Wyżkiewizc, 1998; Waltke, 2005 \& Dell, 2006). It is necessary to recognize that the Tatar proverbs, also as well as proverbs of other people of the world are used in two values: direct and figurative. The complexity of transfer of the Tatar proverbs in the European languages is connected with that the majority of them cannot be taken literally as then, they get an absurd sense. From all collected proverbs, examples of semantic field "Family" with figurative sense makes about 200 cases that make 92\% from all examples. At the same time as proverbs with direct sense are presented only in 47 examples that makes about $18 \%$ of assembled selection. Complexity in the Tatar culture belongs to nomadic cultures, and culture of the people of Europe to the settled type of culture. This dichotomy causes special tension in the transfer of cultural constants of the Tatar 
ethnos in the European perception.

The Tatar language is in a condition of continuous development; besides, during globalization of economic life of tendency to unification of different spheres of culture even more complicated search of deep meanings in languages and cultures of the minority people (Ryazantsev et al, 2015; Gabdrafikov et al, 2015 \& Pismennaya et al, 2015). The most objective monuments of language culture in our opinion are folklore texts, in particular, monuments of the Tatar national culture (Sayfulina \& Karabulatova, 2014 \& Gilazov et al, 2015). Since understanding by ethnos of the origin, historical destinies, the relations with neighbors (Related and unrelated) and finishing explanation of features of household, mental, family, peoples tribe tenor of life, habits, character of the people and properties of language the folklore as direct traditional creativity of national weight has imprinted in itself all properties of ethnic mentality.(Saville-Troike, 2003). In this regard, it would be desirable to note that some researchers see the isolation of certain subethnic groups of the Tatar people. So, Flera Sayfullina and Irina Karabulatova in detail analyze inner world of the Siberian Tatars, showing that the culture of this group has absorbed in itself cultures of peoples of the North and nearby Kazakhstan (Sayfulina \& Karabulatova, 2014, p. 117). Various researchers specify the difficult ethnic structure of the Crimean Tatars and their distinctive features from Volga region Tatars (Minahan, 2000 \& Fisher, 1987)

The description of ethnic identity on Proverbs of the Tatar people is submitted actually. That causes this relevance, first, numerous contacts between ethnoses unify material and spiritual cultures of the nations, change habits and behavior of people, influence their values that leads to lose of individual and ethnic identity. Loss of cultural values even one small people conducts to the impoverishment of culture of all humanity. Secondly, the analysis and interpretation of rich folklore material of the Tatar people testifies to the uniqueness of components of the spiritual culture of Tatars, which needs to be kept. Therefore, also its need of fixing the system of the ethnic differentiating signs existing typical is not the less actual reason for studying the ethnic identity of the Tatar people. In the third, theoretical material studying the designated problem shows that, despite prevalence of proverbs in the Tatar language, researches in the field of ethnic identity on Tatar people folklore materials have private and limited character. In the fourth, the relevance of this research is that it is in the course of linguistic and cultural studying of the creative heritage of ethnos, and its results allow defining aspects, the cornerstone ethnic identity.

\section{Initial Material and Methods of Processing}

The functional description of the Tatar proverbs semantic field "Mine/Alien" and "Family" we combine with cognitive approach realizing it on the wide sociocultural background. As we know Language is in indissoluble communication with culture: those lines of reality which are represented relevant for carriers of the corresponding culture find reflection in language (Karabulatova \& Polivara, 2013). The issue of the relationship between language and culture is due in large part to the search of a universal and concrete perception of reality bearers of different linguocultural traditions (Waltke, 2005 \& Dell, 2006; Gilazetdinova et al., 2014).

Current research is devoted to studying of ethnic identity on Proverbs of the Tatar people. From our point of view, research of ethnic identity on folklore texts, in particular, on national Proverbs presents particular interest. One of the aspects of such research is the complex analysis of key to the cultural concepts on separate language material, certainly, that is obligatory in the detection of ethnic features of various people mentality. National and cultural detailed detection needs associative thinking specifics of various linguocultural community representatives due to the fact, that the world naive picture analysis is a reliable research method of the national-cultural peculiarities of the linguistic consciousness of speakers of those or other languages and cultures. The subject of this research is communication and linguistic features of ethnic identity designing. The proverbs of Tatar language is the object of research.

Texts of the proverbs collected by $\mathrm{N}$. Isanbet were the primary source of the material (Isanbet, 1967). The analyzed material is extracted by the method of continuous selection of this dictionary. As language material for this research, about 200 Tatar proverbs have served to display perception situations by the person, which are fixed in phraseological value or internal form of paremias. The main attention in the analysis was paid to the value of the Tatar proverbs. Studying of language in close connection with the person, his consciousness, thinking and practical spiritual activities are the priority directions of modern linguistics. A paremiological layer of languages is very interesting material where it is clearly visible "language - culture - ethnos".

Theoretical importance consists in that, that the actual material introduced into scientific circulation and theoretical conclusions will serve further development of the theory of ethnic identity according to the folklore text. Research of the ethnic-differentiating signs on the material of proverbs of Tatars with the use of the approved technique will allow adding and expanding ideas of the Tatar ethnic identity. Also, the theoretical importance of work consists in the description of linguistic means of identity construction. 
Practical significance consists in that material that the presented research can be applied to pedagogical activity: in courses of ethnic-sociology, cultural science, social anthropology, ethnography, sociolinguistics, stylistics. Materials and conclusions of work can be useful to students of the humanitarian cycle of the not linguistic specialties studying public relations, advertising, journalism, psychology, and sociology.

The methodological basis of work is caused by the character of the interpreted material. The purposes and problems of work assumes application of traditional research methodology in linguistics.

The primary goal of our work is a descriptive method that is implemented in all of the following methods: observation, comparison, generalization and classification of the material analyzed. Also have been used the descriptive method, method of continuous selection of the original material of card file, elements of the quantitative analysis, pragmatically and substantial analysis, content analysis.

Theoretical research base has made works of such researchers of Tatar folklore language as G. A. Nabiullina (Nabiullina, 2014; Zamaletdinov et al., 2014), E.N. Denmukhametova (Denmukhametova, 2009) and G.R. Mugtasimova (Mugtasimova, 2012); also the works devoted to the Tatar linguistic cultural studies of R.R. Zamaletdinov (Zamaletdinov, 2010) and the questions of identity of A.A. Aminova (Aminova, 2009).It should be noted that ethnic identity of the Tatar people on folklore material never before was the subject of special scientific researches. However in modern domestic literary science more and more actual is an appeal in this context of cross-cultural identity researches in the art measurement. As a rule, such attempts are made to comparative researches.

The novelty of work consists in the analysis of the ethnic identity of the Tatar people on the basis of Proverbs is a new approach to this question's study.

\section{Results of Researches}

The concept "ethnic identity" has the analytical term status (Anderson \& Lee 2005; Kasinitz, Mollenkopf, Waters \& Holdaway, 2008; Phinney \& Ong, 2007; Chao \& Otsuki-Clutter, 2011; Karabulatova, 2013 \& Kiang, Witkow, Baldelomar, \& Fuligni, 2010). It is realized as social identity component of personality and considered base for creation of ethnic consciousness, certain system of behavioural and typical personal distinctive features by means of which the individual is recognized as the member of group (Torres \& Ong, 2010; Mugtasimova et al., 2014; Nabiullina et al., 2014). Identity follows from identification process: the person associates the lines with certain qualities, characteristics and opinions of other person or the whole group. Scientists include in ethnic-defining characteristics also perception and thinking ways, the steadiest features of communication and behavior which occur thanks to belonging to certain ethnos. There are some examples of proverbs: Үз кешең белән даулашма, ятны яклашма - Do not quarrel with your friends, do not defend someone else's; If you connect strings - the lasso will turn out; The house with two hostesses is dirty.

The process of ethnic identification is one of the most important in knowledge and traditions transfer mechanism implementation. Therefore, the regularities connected with this process could not but be reflected and in semantic space of the Tatar proverbs. One of the major categories characterizing self-identification process is category «Y $3-$ Я - Alien»). This category is one of the fundamental axes of attitude, the most important world categorization cognitive basis. The analysis of the Tatar Proverbs shows that the vast majority of them possesses positive semantics in what ethnic identity is shown. "Mine" is estimated by Tatars above (it better and closer), than "Alien."

So, in theme group of proverbs «Y 3 - Yat» («Mine - Alien ») is expressed some leading generalized meanings:

1) Positive assessment "of": Үзеңнең чәчең ятның башыннан кадерлерәк - The hair is more expensive than its alien head; Үз сөягең үзеңнән артмас - A burden of one's choice is not felt;

2) Negative assessment of "Alien": Ят кешенең баскычы каты - The stranger has rigid ladder; Ят кашыгы авыз ерта - An empty hand is no lure for a hawk.;

3) Unification "of":Үзеңнеке бер этсә, бер тарта - The both pushes and pulls; Үзеңнекенә сүз үтә - With her we can agree; Үзеңнеке үз булыр, бүзле киндер көз булыр - Myne closer to him; Үзеңнеке - үзеңә, ай күренер күзеңә - Yours is yours, the moon will be visible to your eyes.

The Tatar proverbs with negative semantics reflect the indifferent relation to alien problems and troubles: Үзеңнеке үзәктә, кешенеке кештәктә - Yours in the center, someone else on the side.

Thus, depending on situations Tatars identifies itself either with "Mine" with "Alien", and relationship "Mine" and "Alien" is caused by requirement and benefit. You should not always think "as all" - Атасы башканың йоласы башка, бабасы башканың догасы башка, but it is necessary to know what about they speak- Серләшергәүз яхшы, сөйләшергә ят яхшы. Who is "Mine", and who is «Alien», the person decides finally selecting the position for the evaluation, in accordance with which category may become insignificant «good - bad», «the necessary unnecessary»:Үз кешең белән даулашма, ятны яклашма - Do not quarrel with your friends, do not defend someone 
else's; Бар вакытта ят яхшы, юк вакытта үз яхшы - When there is good aliens, then there is no - yours good. Thus, you will not share "Mine" misfortune neither with the friend nor with the enemy as evidenced paremic options: Һәркемнең үз гадәте- Everyone has their custom.

One more unit, which contents is embodied in the Proverbs testifying to the position of self-identification of Tatars is «Гаилә» («Family»). The relation in the family is one of the most interesting and many-sided subjects in the Tatar paremiology. For the characteristic of the family and related relations those proverbs are used to indicate either the closest or the weakest related communications. For example, Тиң тиңе белән, итәк жиңе белән - On an equal footing with equal, the skirt with sleeve is good; Миләш дип капкан идем, балан булып чыкты бу - I thought raspberry, but proved viburnum; Агачына күрә алмасы, анасына күрә баласы - Tree- apple, mother-child; Ир бирмәк - жан бирмәк - To give the husband - to give soul.

The Tatars have a positive attitude towards marriage; note the importance of this event in a person's life, the need to treat this with the utmost seriousness and responsibility. Өйләнү - кеше гомерендә бер килә - Marriage - takes place once in the life of people; Өйләну базарга чыгып ат алып кайту түгел - Marriage - is not buying the horse at market; Өйләнү тун тегеп кию түгел, ярамаса сатып котыла алмассың - Marriage is not a coat sewing, if you do not fit, you can not sell it. There are more proverbs in the Tatar language, which embody the possibility of all-around characteristics of family relationships. It is manifested in the relations between personality traits of people. Proof of this are such proverbs - Карама беләккә, кара йөрәккә - Do not judge him by his strength of hands, but see what spirit he has; Төсенә карама, эшенә кара - Do not look at color, look at work; Алгы көпчәк кая тәгәрәсә, арты шуннан тәгәри - Where forward wheel, there is back wheel; Хужасы кемне кабул итсә, эт шуңа койрык болгар - The owner who takes, the dog will wave its tail for him.

Clear and devoted love - here those relations which are highly appreciated by the Tatar people: Мәхәббәт акчага сатылмас, күңел акчага табылмас - The love for money is not on sale, I smother not perhaps to find money; Бозыклык ишектән керсә, гыйшык тәрәзәдән чыгып китәр - The debauchery sets, the love leaves; Жаның уртак булса да, ярың уртак булмасын - The soul can be general, but darling - none; Мәхәббәт сәдака түгел, теләсә кемгә биреп булмый - Love is not a charity, you do not give it just to anyone; Матур да күп, чибәр дә күп, жан сөйгәне бер генә Beautiful there is a lot of, but darling is one; Бизмән белән гер бергә, хатын белән ир бергә - Balance and weight together is similar to husband and wife together. Indeed, honesty, loyalty, self-sacrifice - the quality of those who know how to be friends and love. Quite the opposite sense to have the following proverb: Уңмаган хатының булганчы, уңган этең булсын - Than wife incapable, the capable dog is better; Иргә таянма, илгә таян - Do not hope for the husband, hope for people; Татлы дошман - ир, имеш, дип әйтте ди бер хатын - The husband - the sweet enemy, has told one woman.

Tatars condemn hypocrisy, treachery and revenge: Хатыны яман ир азар - At the bad wife the husband whores; Ике кыйблага оеганның иманы булмас - Who looks in two parties, that has no belief. Proverbs are advised, however: Ачы булса да, дөресен сөйлә - Even if it is not sweet, tell the truth.

Often family life is not all right, in fact, often things get complicated, problematic situations arise: Тавык керсә, чүп чыгар, ят керсә, сүз чыгар If the chicken will enter, the garbage turns out, when will somebody enter, the words will be heared.

Number of proverbs reflect as the beginning of the relations between spouses (Кем белән баш кушсаң, шуның белән гомер итәрсең - То whom has connected, with that and you will live), and rupture of the family and related relations (Кушылмак уңай, аерылмак кыен - It is well to connect, badly to leave; hәр кавышмакның соңында бер аерылмак бар - At the end of each meeting there is partying).

Quite often situations when partners, constantly communicating with each other meet, do not perceive information about each other, about own qualities, habits, interests and affairs. And as a result, cases when family disorders become property of the public: Ирнең атын хатын чыгарыр, хатынның атын ятим чыгарыр - The wife will glorify the husband, the orphan will glorify the woman; Күп кыбырсыган хатын, чыгарыр ирнең яман атын - Fussy wife ill fame husband; Ир хурлаганны ил хурлар, ир мактаганны ил мактар - Who is derided by the husband, that is derided by the world, who is praised by the husband, that is praised by the world; Ир какканны ил кагар - Who is oppressed by the husband, that is oppressed by the world.

Usually at Tatars people around try to make impact on the course of the relations in family: Ходай кушылдырганны кеше аера алмас - Whom God has joined, man can't divide them; Майламыйча, таба да купмый Not brushing and frying pan not atlases; Сәбәбен күрмичә, сәнәгең булмый - Without seeing the reason, the weapon will not be. In this situation proverbs warn: Ир белән хатын арасына кыл да сыймый - Between the husband and the wife's hair will not even pass; Ир белән хатын икесе бер чыбыктан сөрелгән - The husband, and the wife are made of one twig; Ир белән хатын икесе бер камырдан (әвәләнгән) - The husband and the wife are made of one dough. 
Summarizing, should be noted that Proverbs of the Tatar people are a concentration of background knowledge for identification of the people, help to study culture, mentality more deeply.

\section{Conclusion}

Taylor, analyzing proverbs, specifies that the proverb is the unique invention of the person where basic knowledge of the people about reality is in common form reflected. This knowledge is given laconic shape passes from father to son (1994, p. 8). Proverbs are used in identity designing as they carry out two language functions - discursively (closely connected with cumulative) and socialization function. The first function reflects person informative processes (thinking), formation and thoughts logical connection in time thanks to what language acts as individual thinking tool base which proceeds, like a rule, in verbal forms. Thereof "research of language is one of the ways of studying of thinking" (Shkolovaya, 2005 \& Öztürkmen, 1992).

Some philologists researches directed on ethnic identity studying. They are connected mainly with folklore material studying, separate components specifics of structure, however, and began to be made recent attempts of idioms studying in various discourses (Romero, Meeder \& Kleinberg, 2015). Definition and description of the ethnic identity on such material are undertaken in the book V.A. Glukhov \& N.N. Glukhov "System reconstruction of the Mari ethnic identity". In the monograph, ethnic identity is understood as identity of the culture of ethnos to itself. Ethnic identity is considered as a system. This assumption is based on an understanding of human culture, in a certain order of elements (components, values) including language, religion, morals, art, science, and equipment. According to V.A. Glukhov and N. N. Glukhova difficulty of determination of ethnic identity consists in the lack of standard using that it is possible to measure and interpret ethnic origin. In the specified monograph, the solution to this problem is proposed, and as a result of the reconstruction of three leading subsystems of national experience by authors the folklore standard of the Mari ethnic identity is built. The innovative complex technique receives it means including as use of humanities traditional receptions, and the quantitative assessment that is carried out using coefficients of linear correlation (Glukhov, 2007; Yusupova et al., 2014).

\section{Conclusion}

Summing up the Tatar people ethnic identity research problems research, it is possible to conclude, that the problems considered in the article, certainly, do not cover all range of questions, concerning phenomenon of ethnic identity. We consider important to note that many questions raised in article demand special studying and make, in our opinion, the prospect of further researches of ethnic identity.

The value of linguistic work in the field of identity consists in the understanding of the importance of those speech efforts that are made by the person for the statement of in this world. Language is one of the most important means of familiarizing with personal and others' culture, and also awareness of ethnic identity. Thus, in the paremic case of the Tatar language the most ancient and steady archetypes of ethnic consciousness created at the formation of the nation are postponed. In proverbial sayings, the Tatar people speak about themself.

So, for studying the problem of ethnic identity also the folklore, namely proverbs as possess own, special reliability and the special objectivity can be a reliable source. The following provisions cause the choice of folklore. In its typical situations of the relations are reflected in spheres: person, person society, person nature. Through folklore completeness, ethnos life way as it reflects all significant parties of human activity is shown, forms variety of norms and data on the world around and, as a result - behavior model of the person. At last, the folklore, owing to the general availability, is used for various segments of the population, providing, thereby, continuity in space and in time.

National aphorisms carry out some cognitive and pragmatically functions, being a manifestation of an active aspect of popular wisdom, is active in respect of broadcast of the codes of culture necessary for the preservation of ethnic identity. Considering Proverbs, we allocate some problem situations in which it is accepted to appeal to popular wisdom fund, - first of all, these are the issues connected with a person personal space concept - self-identification problem. In

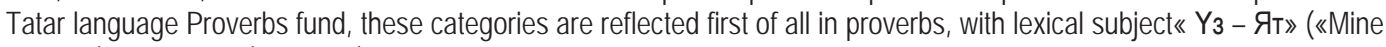
- Alien») и «Гаилә» («Family»).

In summary, it should be noted that traditional values of local cultures, their historical past, and religious views have still essential impact on the formation of deep layers of identity. Preservation of own traditions and cultural wealth and their promotion in the world, the formation of the feeling of national pride at respect for other people have to become the basis of ethnic identification in the modern world. 


\section{References}

Aminova, A.A. (2009) Cultural identity and problems of language communication. B: Scientific notes of the Kazan University. Series: Humanities, 151 (3).

Anderson, Wanni W. \& Robert, G. Lee (2005) Displacements and Diasporas: Asians in the Americas. New Brunswick: Rutgers University Press.

Gabdrafikov, I.M., Karabulatova, I.S., Khusnutdinova, L.G. \& Vildanov, Kh.S. (2015) Ethnoconfessional Factor in Social Adaptation of Migrant Workers in the Muslim Regions of Russia. In the: Mediterranean Journal of Social Science. 2015. Vol 6, No3, Supplement 4, May 2015. pp. 213-223.

Gilazetdinova, G.Kh., Edikhanov I.Zh. and Aminova. A.A. (2014). Problems of ethnocultural identity and cross-language communication. Journal of Language and Literature; 5(3), pp. 39-42.

Glukhov, V.A. \& Glukhova, N.N. (2007) System reconstruction of the Mari ethnic identity. Joshkar-Ola.

Chao, R.K., \& Otsuki-Clutter, M. (2011). Racial and Ethnic Differences: Sociocultural and Contextual Explanations. In the: Journal Of Research On Adolescence (Blackwell Publishing Limited), 21(1), 47-60.

Dell, K.J. (2006) The Books of Proverbs in Social and Theological Context. Cambridge: Cambridge University Press. Available from http://books.google.com/books [Accessed 26, April 2010]

Denmukhametova, E.N. (2009) Live and inanimate nature in the Tatar paremias. B: Philological Sciences. Questions of the theory and practice. $11(30)$.

Fisher, Alan W. (1987) The Crimean Tatars. Hoover Institution Press.

Karabulatova, I.S. (2013) The problems of linguistic modeling of new Eurasian linguistic personality in the multilinguistic and mental environment (by the example of onomasphere). In the: Middle-East Journal of Scientific Research 17 (6): 791-795.

Karabulatova, I.S. \& Polivara, Z.V. (2013) Turkic, and Slavs: bi-polylinguism in globalization and migrations (on an example of Tumen region). In the: Middle-East Journal of Scientific Research 17 (6): 832-836.

Karabulatova, I.S., Koyche, K.K. \& Gultyaev V.N (2013) The Dialogue of Kazakh Steppe and Russian Forest: About the Character of Turkic-Speaking Linguistic Personality on the Territory of Russian-Kazakhstani Border-Zone.In the: Middle-East Journal of Scientific Research 17 (7): 853-858.

Karabulatova, I.S., Sayfulina, F.S. \& Akhmetova, B.Z. (2013) An ethnic-lingual aspect of the modern functioning of Russian dialects in North Kazakhstan (on an example of Kostanai region). In the: World Applied Sciences Journal Issue 27 (Education, law, economics, language, and communication): 137-140.

Karabulatova, I.S, Polivara, Z.V. \& Zamaletdinov, R.R. (2013) Ethno-Linguistic Peculiarities of Semantic Perception of Language Competence of Tatar Bilingual Children. In the: World Applied Sciences Journal Issue 27 (Education, law, economics, language, and communication): $141-145$.

Karabulatova, I.S. \& Akhmetova, B.Z. (2015) Characteristics of Social-Cultural Vitality of Modern Russian Settlements of the Former Gorky Line of Kazakhstan. In the: Mediterranean Journal of Social Science. 2015. Vol 6, No3, S4, May 2015. pp. 201-206.

Kasinitz, Philip, John, H. Mollenkopf, Mary C., Waters \& Jennifer Holdaway (2008) Inheriting the City: The Children of Immigrants Come of Age. Cambridge: Harvard University Press.

Khachmafova, Z.R., Karabulatova, I.S., Luchinskaya, E.N. \& Osipov, G.V. (2015) Gender Features of Discourse of Woman's Literature as a Reflection of Changes in the Modern Society. In the: Mediterranean Journal of Social Science. 2015. Vol 6, No3, S.2, May 2015. pp. 476-481.

Kiang, L., Witkow, M.R., Baldelomar, O.A. \& Fuligni, A.J. (2010). Change in Ethnic Identity Across the High School Years Among Adolescents with Latin American, Asian, and European Backgrounds. Journal Of Youth \& Adolescence,39(6),683-693.

Mingazova, L. \& Sulteev R. (2014) Tatar end English Children's Folklore: Education in Folk Traditions. Publication: Western Folklore. Vol 73, No 4.

Minahan, James (2000) Europe, many nations: a historical dictionary of European national groups. https://books.google.de/books?id= NwvoM-ZFoAgC\&printsec=copyright\&hl=ru\#v=onepage\&q\&f=false ([Accessed 6, August 2015).

Mugtasimova, G.R., Nabiullina G.A. and Denmukhametova E.N. (2014). Paremiological Fund of the Tatar people in the ethnolinguistic aspect. Life Sci J, 11(11), 409-412. http://www.lifesciencesite.com. 69.

Nabiullina, G.A., Denmukhametov, E.N. \& Mugtasimov, G.R. (2014). Lexicon and Syntax of the Tatar proverbs. Philology and culture. 4 (38).

Nabiullina, G.A., Denmukhametova E.N. and Mugtasimova G.R. (2014). The linguistic characteristics of Tatar Paroemiae. Life Sci J, 11(5), 559-562. http://www.lifesciencesite.com. 85

Neroznak, V.P. (1994). The modern ethnwc language situation in Russia. News of the Russian Academy of Sciences. Series of literature and language. 53 (2).

Ostrovskaya, T.A., Karabulatova, I.S., Khachmafova, Z.R., Lyaucheva, S.A. \& Osipov G.V. (2015) The Discourse of the Russian Elite in the ERA "Liquid" Modernity as a Problem of Ethnic, Social and Cultural Security. In the: Mediterranean Journal of Social Science. 2015. Vol 6, No3, S4, May 2015. pp. 147-154.

Öztürkmen, Arzu (1992) Individuals and Institutions in the Early History of Turkish Folklore, 1840-1950. Journal of Folklore Research.Vol. 29, No. 2 (May - Aug. 1992), pp. 177-192.

Hrolenko, A.T. \&, Bondaletov, V.D. (2004). Theory of language: studies. grant. Moscow, Feint: Science.

Shkolovaya, M. (2005) Linguistic and semiotics aspects of designing of identity in electronic communication (The thesis of competition of 
academic degree of Candidate of Philology). Tver.

Phinney, J.S. \& Ong, A.D. (2007). Conceptualization and measurement of ethnic identity: Current status and future directions. Journal of Counseling Psychology, 54, 271-281.

Pismennaya, E.E., Karabulatova, I.S., Ryazantsev, S.V., Luk'yanets, A.S. \& Manshin, R.V. (2015) Impact of Climate Change on Migration from Vietnam to Russia as a factor of Transformation of Geopolitical Relations. In the: Mediterranean Journal of Social Science. 2015. Vol 6, No3, S.2, May 2015. pp.:210-215.

Romero, Daniel M., Brendan, Meeder \& Jon Kleinberg (2015) Differences in the Mechanics of Information Diffusion Across Topics: Idioms, Political Hashtags, and Complex Contagion on Twitter, 2015. http://www.cs.cornell.edu/home/kleinber/www11hashtags.pdf (electronic resource, date of the appeal to base 10.09.15).

Ryazantsev, S.V., Pismennaya, E.E., Karabulatova, I.S. \& Charif, Y.Akramov (2014) Transformation of the sexual and matrimonial behavior of Tajik labor migrants in Russia. In the: Asian Social Science. Vol 10, No.20, 2014, pp: 174-183.

Ryazantsev, S.V., Karabulatova, I.S., Sivoplyasova, S.Yu., Pismennaya, E.E. \& Manshin, R.V. (2015) Modern Aspects of Human Trafficking in the Context of Labor Exploitation and Irregular Labor Migration in the Russian Federation. In the: Mediterranean Journal of Social Science. 2015. Vol 6, No3, S.2, May 2015. pp.: 67-72.

Sayfulina, F.S., Karabulatova, I.S., Yusupov, F.Yus. \& Gumerov, I.G. (2013) Contemporary issues of textual analysis of Turkic-Tatar literary monuments of Western Siberia. In the: World Applied Sciences Journal Issue 27 (Education, law, economics, language, and communication): 492-496.

Sayfulina, F.S. \& Karabulatova, I.S. (2014) European studies of barabin tatar folklore: the role of investigations of the german scientist V.V. Radlov. In the: Life Science Journal, 2014, 4; 11 (9): 116-119.

Saville-Troike Muriel (2003) The Ethnography of Communication. An Introduction Third Edition. Oxford

Taylor, A. (1994). The Wisdom of Many and the Wit of One, in Mieder, W. \& A. Dundes. The Wisdom of many: Essays on the Proverb. Madison, Wisconsin: University of Wisconsin Press. 3-9. Available from http://books.google.com/books [Accessed 26, April 2010].

Torres, L. \& Ong, A.D. (2010). A daily diary investigation of Latino ethnic identity, discrimination, and depression. Cultural Diversity and Ethnic Minority Psychology, 16(4), 561-568.

Yusupov, F.Yu. \& Karabulatova, I.S. (2014) Some results of the research system-synchronous modern dialect of the Tatar language. In the: Life Science Journal. 11 (7s): 246-250.

Zamaletdinov, R.R., Yusupov, F.YU., Karabulatova, I.S., Yusupov, A.F. \& Husnutdinov D.H. (2014) The formation of tatar ethnic groups in the southern urals and trans ural region. In the: Life Science Journal. 11(11s): 214-217.

Zamaletdinov, R.R., Karabulatova, I.S., Yarmakeev, I.E. \& Ermakova E.N. (2014) Linguo-propaedeutics of ethnic conflicts as a basis for stability in complex polyethnic regions. Asian Social Science, 2014. Vol.10, No.20, 164-173.

Zamaletdinov, R.R. \& Zamaletdinova, G.F. (2010). Roles of proverbs in the research of national culture patterns of language consciousness. Philology and culture. 20.

Mugtasimova, G.R. (2012). Ethnocultural patterns of the Tatar riddles. Philological Sciences. Questions of the theory and practice. 7-2 (18).

Wyżkiewizc, R. (1998) Representation of the Home/House in Polish and Serbian Proverbs, in Ďurčo, P. (ed.). Europhras '97: Phraseology and Paremiology. Bratislava: Akadémia PZ. 366-369.

Waltke, B.K. (2005) The Book of Proverbs: Chapters 15-31. Grand Rapids/Cambridge: Wm. B. Eerdmans Publishing Co.

Yusupova, A.S., Galiullina G.R. and Denmukhametova E.N. (2014). Representation of national mentality in Turkic-Tatar vocabulary. Life Science Journal,11 (7), 256-258.

Zamaletdinov, R.R.; Zamaletdinova G.F., Nurmukhametova R.S. and Sattarova, M.R. (2014) The lexicon and its reflection in the inner world of the individual (on the basis of the Tatar Language). Journal of Language and Literature, 5(4). pp. 333-335. 